\title{
The Influence of the Genetic and Immunologic Context in the Development of Colorectal Adenoma: A Case Series Report
}

\section{A Influência do Contexto Genético e Imunológico no Desenvolvimento do Adenoma Colorrectal: Uma Série de Casos}

Diogo GARCIA® ${ }^{1}$, Louisa SPAANS ${ }^{2}$, Sara MIRANDA³ , Gilza GONÇALVES ${ }^{4}$, Joana REIS ${ }^{3}$, José Luís COSTA³, Cecília DURÃES ${ }^{3}$, Fátima CARNEIRO 1,3,4,5,6, José Carlos MACHADO ${ }^{1,3,4,5}$

Acta Med Port 2020 May;33(5):297-304 - https://doi.org/10.20344/amp.12462

\section{ABSTRACT}

Introduction: Overcoming immunosurveillance is a major step in the progression of many types of tumors. Several immune escape strategies have been identified, including immunoediting and the establishment of an immune suppressive microenvironment. The aim of the present study was to determine whether the hereditary or sporadic context has any influence in the relationship between immune surveillance and tumor development, using sporadic and familial adenomatous polyposis related colorectal adenomas as a model. Material and Methods: The immune tumor-infiltrating cells of a total of 58 low-grade and 18 high-grade colorectal adenomas were examined and compared, using immunostaining for CD3, CD4, CD8, CD57, CD68 and FoxP3.

Results: FoxP3 and CD68 counts were significantly higher in sporadic low-grade dysplasia $(p=0.0003$ and $p=0.0103$, respectively), and FoxP3 and CD4 counts were found to be significantly higher in high-grade sporadic dysplasia $(p=0.0008$ and $p=0.0018$, respectively) when compared with corresponding lesions in patients with familial adenomatous polyposis.

Discussion: This study suggests that the immune microenvironment of sporadic and hereditary lesions is different. Sporadic lesions contain a higher number of immune suppressive Treg cells, which suggests a stronger immune selective pressure. In contrast, hereditary lesions seem to benefit from a more tolerant immune microenvironment, allowing for the development of lesions with lower immune cell infiltration.

Conclusion: This study shows that sporadic lesions harbor higher tumor-infiltrating immune cell counts, which might reflect a higher immune tolerance towards hereditary lesions.

Keywords: Adenoma/diagnosis; Adenoma/genetics; Colorectal Neoplasms/diagnosis; Colorectal Neoplasms/genetics; Immunohistochemistry

\section{RESUMO}

Introdução: A capacidade de contornar a imunovigilância é fundamental na progressão de muitos tumores. Já foram identificadas várias estratégias de escape imunológico, incluindo immunoediting e o estabelecimento de um microambiente imunológico supressivo. O objetivo do presente estudo passa por determinar se o contexto hereditário ou esporádico influencia a relação entre a imunovigilância e o desenvolvimento do tumor, usando adenomas coloretais esporádicos e hereditários, no contexto de polipose adenomatosa familiar, como modelos.

Material e Métodos: Os infiltrados imunológicos tumorais de um total de 58 adenomas coloretais de baixo grau e de 18 de alto grau foram avaliados e comparados, usando imunohistoquímica com marcação para CD3, CD4, CD8, CD57, CD68 e FoxP3.

Resultados: As contagens celulares com imunorreatividade para FoxP3 e CD68 foram significativamente mais elevadas na displasia esporádica de baixo grau ( $p=0,0003$ e $p=0,0103$, respetivamente), enquanto que as contagens para FoxP3 e CD4 foram significativamente mais elevadas na displasia esporádica de alto grau ( $p=0,0008$ e $p=0,0018$, respetivamente) quando comparadas com lesões correspondentes em doentes com polipose adenomatosa familiar.

Discussão: O presente estudo sugere que o microambiente imunológico de lesões esporádicas e hereditárias é diferente. As lesões esporádicas contam com um número superior de células T reguladoras, supressoras da função imunológica, sugerindo-se uma pressão imune seletiva mais forte. Por seu turno, as lesões hereditárias parecem beneficiar de um microambiente imunológico mais tolerante, permitindo o desenvolvimento de lesões com menor infiltrado celular imune.

Conclusão: Este estudo demonstra que as lesões esporádicas contam com contagens de infiltrados imunológicos tumorais superiores, o que poderá refletir uma maior tolerância imunológica face a lesões hereditárias.

Palavras-chave: Adenoma/diagnóstico; Adenoma/genética; Inmunohistoquímica; Neoplasias Colorretais/diagnóstico; Neoplasias Colorretais/genética

\footnotetext{
1. Medical Faculty. University of Porto. Porto. Portugal.

2. Maastricht University. Maastricht. The Netherlands.

3. Instituto de Investigação e Inovação em Saúde. Universidade do Porto. Porto. Portugal.

4. Institute of Molecular Pathology and Immunology. Universidade do Porto. Porto. Portugal.

5. Department of Pathology. Medical Faculty. University of Porto. Porto. Portugal.

6. Department of Pathology. Centro Hospitalar e Universitário São João. Porto. Portugal.

$\triangle$ Autor correspondente: Diogo Garcia. diogo.monizgarcia@gmail.com

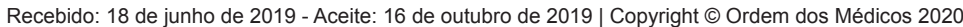




\section{INTRODUCTION}

Colorectal cancer (CRC) is the third most common cancer in men and the second in women. ${ }^{1}$ Despite recent improvements, which include the introduction of new chemotherapeutic agents, the outcome for most patients remains relatively poor. ${ }^{2,3}$ Therefore, additional treatment options beyond standard therapies (including surgery, chemotherapy and radiotherapy) are needed. There is renewed interest in immunotherapeutic options as there is a growing body of evidence supporting the existence of cancer immunosurveillance. ${ }^{4}$

Immunosurveillance exerts an important influence in tumor progression and in the efficacy of anti-cancer therapies. ${ }^{5}$ Its success depends on the ability to detect neoantigens, frequently generated through mutations. Whether tumor-infiltrating lymphocytes represent the result of an inflammatory response that facilitates tumor progression, or a protective host response remains controversial. ${ }^{4}$

The presence of a pronounced lymphocytic infiltration within the tumor is associated with improved survival ${ }^{6-14}$ and several studies have indicated a relationship between the number of infiltrating tumor CD8+ T lymphocytes and an improved prognosis in CRC. ${ }^{15-18}$ Furthermore, the presence of high levels of tumor infiltrating memory $T$ cells within CRC tissue has been associated with the absence of early metastatic spread and an improved disease-free and overall survival. ${ }^{19}$ Moreover, the amount of activated intraepithelial CD8+ lymphocytes infiltration in CRC is related to stage, which might indicate that immune reaction is more prominent in early stages of disease and might have a stage specific influence on survival. ${ }^{20,21}$ It is also currently known that immune dysregulation is already present in the early stages of the adenoma-CRC sequence..$^{22}$

There are multiple pathways in colorectal cancer pathogenesis, which include the chromosomal instability (CIN), microsatellite instability (MSI) and $\mathrm{CpG}$ island methylator phenotype (CIMP) pathways. ${ }^{23} \mathrm{CIN}$ pathway is particularly suited for this study, since it includes, in most cases, a systematic progression through precursor lesions, which allows the study of the immune system activity in different stages of normal, precancerous and cancerous lesions of the colon. A key early mutation in the chromosomal instability (CIN) pathway is the mutation of adenomatous polyposis coli (APC) tumor suppressor gene. Familial adenomatous polyposis (FAP) is an autosomal dominantly inherited syndrome caused by germline mutations in the APC gene that accounts for approximately $1 \%$ of all CRCs. ${ }^{24}$ Affected individuals develop hundreds to thousands of adenomas in the colon and rectum at unusually young ages. If left untreated, one or more adenomas progress invariably to CRC.

Inherited genetic variants have been demonstrated to affect both baseline and induced host immune responses. In fact, anti-tumor immune responses are intrinsic characteristics, controlled, in part by the host's genome. ${ }^{25-27}$ However, such characteristics have yet to be systematically studied in hereditary models of cancer. A similar line of thought can be followed for somatic genetic variants. Since sporadic lesions typically originate much later (10 - 30 years) than hereditary lesions, one would predict the baseline mutation burden to be higher in sporadic lesions. This in turn, should translate into higher immunogenicity in sporadic lesions when compared with hereditary lesions.

The aim of the present study, using sporadic and FAPrelated colorectal adenomas as a model, was to determine whether the hereditary or sporadic context has any influence in the relationship between immune microenvironment and tumor development.

\section{MATERIAL AND METHODS \\ Case selection}

A total of 58 patients were selected from Centro Hospitalar Universitário São João, Porto, Portugal who had undergone either resection or biopsy (one single case). Twenty-seven FAP cases (14 male and 13 female), diagnosed between 1999 and 2015, and 31 sporadic cases (16 male and 15 female), diagnosed between 2016 and 2018 were used. Normal mucosa, low-grade dysplasia and highgrade dysplasia were analyzed. All lesions were located in the colorectum, with the exception of one lesion located

Table 1 - Immunohistochemistry (IHC) protocol and staining patterns

\begin{tabular}{|c|c|c|c|c|c|}
\hline Antibody & $\begin{array}{c}\text { Type/Clone } \\
\text { of primary Antibody }\end{array}$ & $\begin{array}{l}\text { CC1 solution's } \\
\text { exposure time } \\
\text { (minutes) }^{*}\end{array}$ & 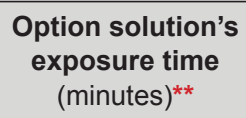 & $\begin{array}{l}\text { Antibody's exposure } \\
\text { time (minutes) }\end{array}$ & $\begin{array}{l}\text { Staining } \\
\text { pattern }\end{array}$ \\
\hline Anti-CD3 & $\begin{array}{l}\text { Anti-CD3 (2GV6) Rabbit } \\
\text { monoclonal primary antibody }\end{array}$ & $40\left(95^{\circ} \mathrm{C}\right)$ & Not used & $20(0.4 \mu \mathrm{g} / \mathrm{ml})^{* * *}$ & $\begin{array}{l}\text { Cytoplasmic and } \\
\text { membranous }\end{array}$ \\
\hline Anti-CD4 & $\begin{array}{l}\text { Anti-CD4 (SP35) Rabbit } \\
\text { monoclonal primary antibody }\end{array}$ & $40\left(95^{\circ} \mathrm{C}\right)$ & 4 & $32(2.5 \mu \mathrm{g} / \mathrm{ml})^{* * *}$ & Membranous \\
\hline Anti-CD8 & $\begin{array}{l}\text { Anti-CD8 (SP57) Rabbit } \\
\text { monoclonal primary antibody }\end{array}$ & $24\left(100^{\circ} \mathrm{C}\right)$ & 4 & $0(0.35 \mu \mathrm{g} / \mathrm{ml})^{* * *}$ & Membranous \\
\hline Anti-CD57 & $\begin{array}{l}\text { Abcam monoclonal mouse } \\
\text { AB } 187274\end{array}$ & 40 & 8 & 28 (1:300 dilution) & $\begin{array}{l}\text { Cytoplasmic and } \\
\text { membranous }\end{array}$ \\
\hline Anti-CD68 & $\begin{array}{c}\text { Anti-CD68 (KP-1) Primary } \\
\text { Antibody }\end{array}$ & $16\left(100^{\circ} \mathrm{C}\right)$ & 8 & $16(0.4 \mu \mathrm{g} / \mathrm{ml})^{* * *}$ & $\begin{array}{l}\text { Cytoplasmic and } \\
\text { membranous }\end{array}$ \\
\hline Anti-FoxP3 & $\begin{array}{l}\text { Polyclonal anti-FoxP3 rabbit } \\
\text { NB } 600-245\end{array}$ & 40 & 4 & 40 (1:300 dilution) & Nuclear \\
\hline
\end{tabular}

*: CC1: Cell conditioning 1 is a prediluted solution used as a pretreatment step in IHC tissue processing reactions carried out in Ventana ${ }^{\mathrm{TM}}$ BenchMark; ${ }^{* *}$ : Prediluted solution ready-touse in order to diminish background staining; ${ }^{* * *}$ : Prediluted antibody solution. 
in the duodenum. Lesions examined in PAF cases were mostly of tubular architecture (14/27), followed by tubulovillous (4/27), villous (2/27) and tubulopapillary (1/27), whilst sporadic lesions were predominantly of tubulovillous architecture (22/31), followed by tubular (7/31) and villous (1/31) varieties.

Patients were matched for gender, but not for age, since CRC pathogenesis occurs at younger ages in FAP patients.

In accordance with Article 19 of Portuguese Law No. $12 / 2005$ of January 26 , no ethical consent was necessary for this study because it was based on the use of retrospective human samples.

\section{Immunohistochemical staining}

Tissue sections were obtained from selected paraffinembedded blocks, which were serially cut with a microtome (microm HM325) at $2 \mu \mathrm{m}$ thickness and mounted on positively charged microscopic slides (Superfrost Plus ${ }^{\mathrm{TM}}$ from Thermo Scientific ${ }^{\mathrm{TM}}$ ). Amygdala was used as a positive control on each slide. Deparaffinization was accomplished with Ezprep at $72^{\circ} \mathrm{C}$ over 20 minutes. Immunohistochemistry (IHC) staining was performed with the Ventana ${ }^{\mathrm{TM}}$ BenchMark ULTRA system. An optimization protocol, approved by a senior pathologist and a lab technician, was performed to achieve appropriate staining conditions. The protocol used is shown in Table 1.

Primary antibodies against CD3, CD4, CD8 and CD68 were added automatically by the Ventana ${ }^{\mathrm{TM}}$ machine with the aforementioned protocols, whilst FoxP3 and CD57 respective primary antibodies were added manually. OptiView $^{\text {TM }}$ Universal DAB detection kit was used.

Haematoxylin was used as a contrast agent $(1 \times 8 \mathrm{~min}-$ utes) followed by Bluing reagent, an after-contrast agent (1 $x 4$ minutes).

After IHC, slide washing was performed with Ezprep (1 $x 10$ minutes), detergent and running water $(1 \times 10$ minutes until clean), followed by dehydration with ethanol $[70 \%(1 \mathrm{x}$ 10 minutes), $95 \%$ (1 x 10 minutes) and 100\% (1 x 10 minutes)] and xylene $(2 \times 10$ minutes). Finally, the slides were mounted with Entellan and a protective slide.
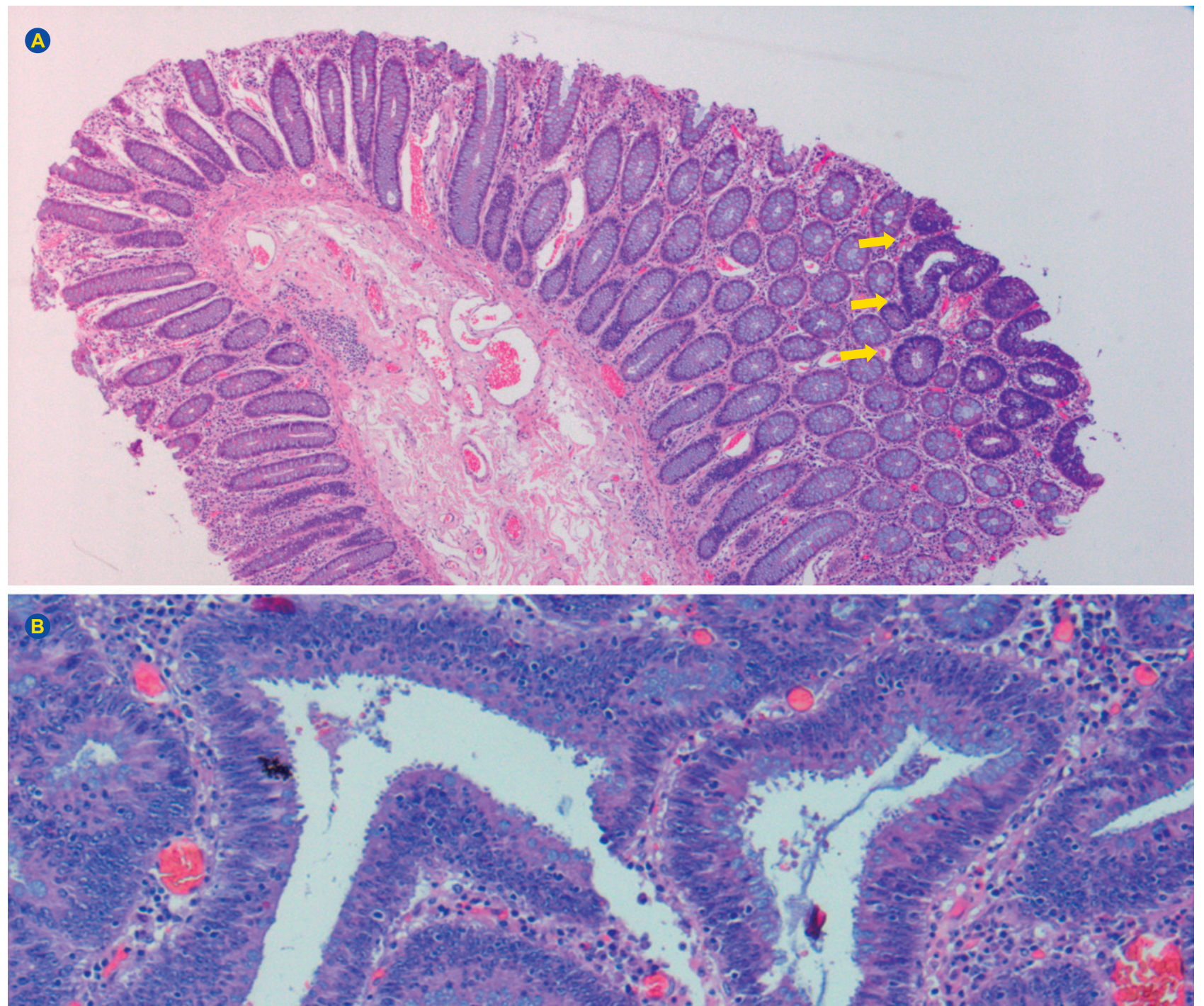

Figure 1 - (A) Normal mucosa (x 4) (left side) and low-grade dysplasia in a familial adenomatous polyposis patient (x 4) (arrows); (B) High-grade dysplasia in a familial adenomatous polyposis patient $(x 10)$. 


\section{Slide analysis}

Haematoxylin and eosin (H\&E) histological slides of each case were reviewed together with a senior pathologist to identify normal mucosa and adenomatous lesions. For each H\&E case, a total of six IHC stained slides were obtained (one slide for each different primary antibody). For each of the IHC slides a total of eight high quality digital color images of the areas were obtained at $40 x$ magnification using an Olympus BX 43 microscope (camera Olympus DP73) (four images of normal mucosa and four images of the dysplastic lesion) for a total of 48 images per case. An example of normal mucosa can be observed in Fig. 1A, of low-grade dysplasia in Fig. $1 \mathrm{~A}$ and of high-grade dysplasia in Fig. 1B.

Each image representing a High-power field (HPF), corresponding to $0.06 \mathrm{~mm}^{2}$ was used to count the stained cells. Individual cells were manually counted by two observers in a double-blind setting, using ImageJ software (National Institutes of Health) that counts the clicks on each cell (cell counter plugin). The entire image was used for counting.

Inflammatory cells within areas of hemorrhage, necrosis, blood vessels, nerves or large lymphoid aggregates were not quantified.

Cells were counted on each of the four images of both normal and adenomatous tissue, corresponding to a total area of $0.24 \mathrm{~mm}^{2}$, respectively.

\section{Statistical methods}

For low-grade dysplasia, the differences in the number of stained cells $/ \mathrm{mm}^{2}$ between normal tissue and lesions were evaluated using unpaired Student's $t$-tests; the difference between the number of stained cells $/ \mathrm{mm}^{2}$ between hereditary and sporadic lesions was tested using unpaired Student's $t$-test.

Regarding high-grade dysplasia, due to the small sample size $(n=9)$ and the presence of several outliers, nonparametric tests were used to infer the difference in the number of stained cells $/ \mathrm{mm}^{2}$ between normal tissue and lesions (Wilcoxon matched-pairs signed rank test); the dif-

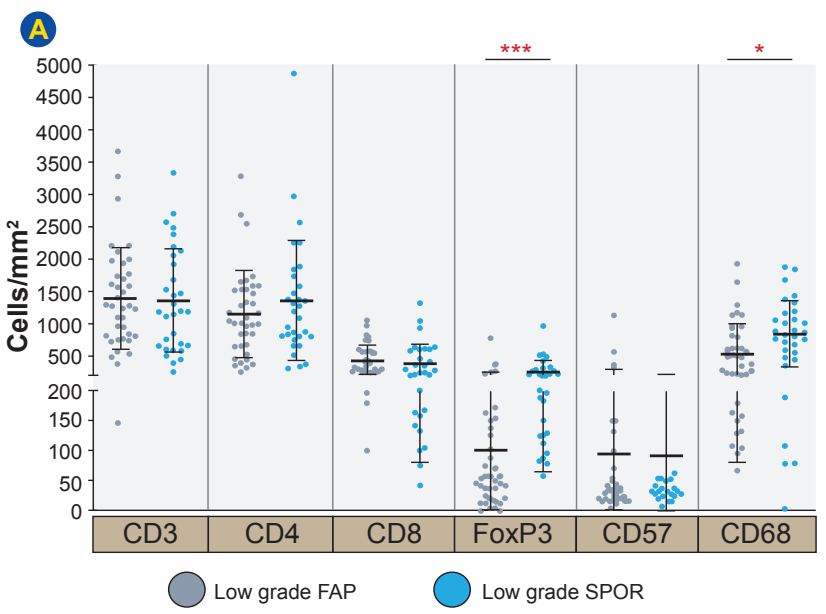

ference between the number of stained cells $/ \mathrm{mm}^{2}$ between hereditary and sporadic lesions was tested using a Mann Whitney test.

\section{RESULTS}

\section{Tumor-infiltrating immune cells}

The tumor-infiltrating cells of a total of 58 cases of lowgrade dysplasia (Fig. 2A) and 18 cases of high-grade dysplasia were examined and compared (Fig. 2B). Immunoreactivity to CD3, CD57 and CD68, exhibiting a cytoplasmic and membranous pattern, to CD4 and CD8, exhibiting a membranous staining pattern and to FoxP3, exhibiting a nuclear staining pattern were analyzed. Immune cell counts were found to be generally higher in the margin than in the tumor in both high-grade and low-grade dysplasia and in both hereditary and sporadic contexts.

Admitting a significance level of 5\%, FoxP3 and CD68positive cell counts were significantly higher in low-grade dysplasia in patients with sporadic CRC $(p=0.0003$ and $p$ $=0.0103$, respectively) when compared with corresponding lesions in FAP patients, whilst CD3, CD4, CD8 and CD57 counts were similar. In high-grade dysplasia lesions, CD4 and FoxP3 counts were significantly higher in patients with sporadic CRC ( $p=0.0008$ and $p=0.0018$, respectively) when compared with corresponding lesions in FAP patients, whilst CD3, CD8, CD57 and CD68 where similar. Examples of low-grade adenomas from both sporadic and FAP patients can be observed in Figs. 3A to 3D, whilst examples of high-grade adenomas can be observed in Figs. 4A to 4D. The comparative analysis of cell counts in familial adenomatous polyposis (FAP) and sporadic (SPO) adenomas is shown in Table 2.

\section{DISCUSSION}

Accumulating evidence supports the importance of the host's immune system on the development of cancer, $7,8,28-32$ which may offer powerful prognostic tools and guide the need for systemic therapy. Immunosurveillance can not only eliminate tumors but also select variant tumor cells that can

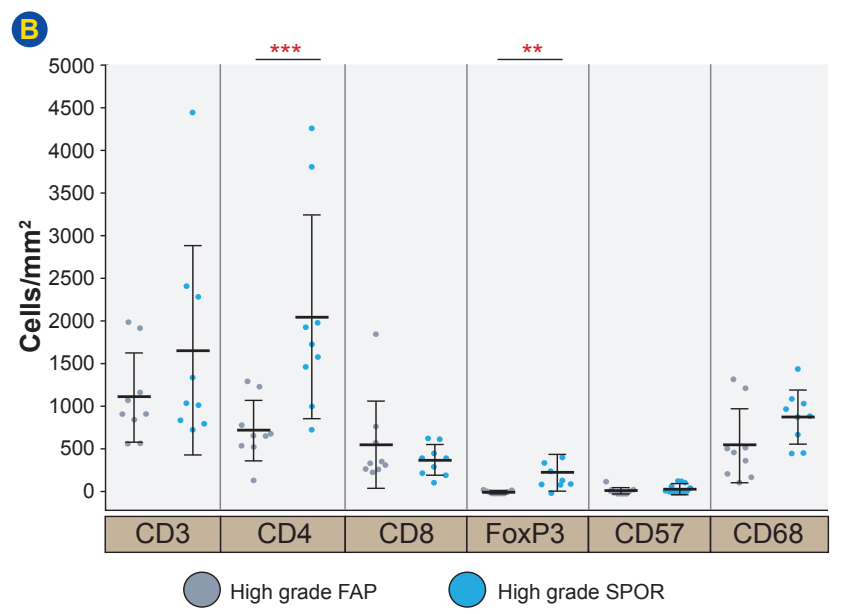

Figure 2 - (A) Low grade dysplasia tumor-infiltrating cells; (B) High-grade dysplasia tumor-infiltrating cells ${ }^{*} p \leq 0.05 ;{ }^{* *} p \leq 0.01 ;{ }^{* * *} p \leq 0.001 ;{ }^{* * *} p \leq 0.0001 ;$ ns $p>0.05$ 

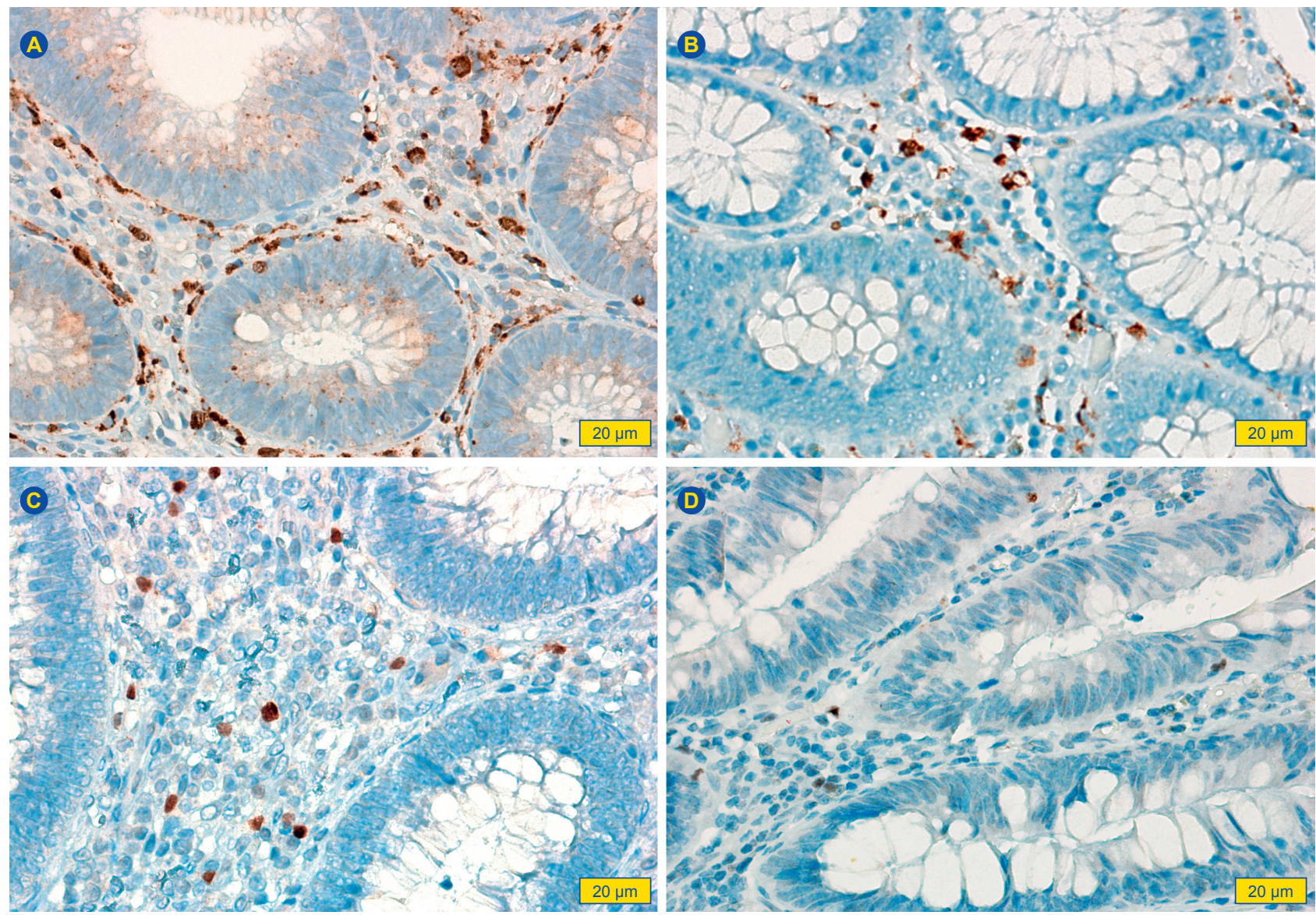

Figure 3 - Low-grade dysplasia (x 40): CD68 stained cells in sporadic (A) and familial adenomatous polyposis (B) adenoma; FoxP3 stained cells in sporadic (C) and familial adenomatous polyposis adenoma (D).

resist it, a process called 'immunoediting' ${ }^{33,34}$ Higher densities of tumor-infiltrating lymphocytes are generally associated with improved clinical outcome. ${ }^{35}$ In particular, higher densities of CD3+ $T$ cells and CD8+ $T$ cells have been associated with longer disease-free survival and/or improved overall survival. Therefore, the role of the adaptive immune response is becoming increasingly appreciated. On the other hand, there is experimental evidence supporting the idea that the innate immune system can promote tumor development through inflammation-dependent mechanisms. ${ }^{36,37}$ Therefore, the precise analysis of the tumor microenvironment by pathologists may be essential for future clinical implementation and better patient management.

Previous studies have examined the independent prognostic effect of tumor-infiltrating immune cells in CRC models, but as far as we know, this is the first study that examines the implication of the hereditary context of FAP in the tumor-infiltrating cells of pre-cancerous lesions.

The current study demonstrates that the hereditary context of FAP results in significantly different phenotypes of tumor-infiltrating immune cells. In sporadic low-grade dysplasia, a significantly higher number of FoxP3 and CD68 stained cells was observed, whilst CD4 and FoxP3 cell counts were significantly higher in sporadic high-grade dysplasia lesions.

Regulatory $T$ cells (Treg) are a subpopulation of CD4+ $T$ cells that express the transcription factor forkhead box protein P3 (FoxP3) and hold a key role in maintaining selftolerance by suppressing the activation and function of self-reactive lymphocytes. ${ }^{38}$ In cancer infiltrates, however, Treg cells suppress the induction and proliferation of effector cells to impair antitumor immunity, contributing to a poor clinical outcome in cancers with abundant Treg infiltration. However, its role in CRC is controversial, having a potentially positive impact by controlling cancer-driving inflammation, whilst, also, promoting tumor progression by impeding specific immune responses. ${ }^{39}$ In fact, higher densities of Treg cells have been associated with better survival in $\mathrm{CRC},{ }^{40,41}$ which might explain the higher counts of FoxP3 stained cells in sporadic lesions, observed in both low grade and high grade dysplasia in the current study. ${ }^{42}$

Tumor-associated macrophages (TAMs), stained with CD68, have been associated with a pro-tumor phenotype in both primary tumors and metastasis, by promoting increased growth, angiogenesis, metastases, immunosuppression and poorer differentiation. ${ }^{43,44}$ Its role in CRC, however, is not as straightforward, and, in contrast to most other malignancies, in CRC, increased macrophage infiltration is associated with better patient prognosis..$^{12,45-50}$ It is likely that infiltrating monocytes are primed in the tumor micro-environment to exert either anti or pro tumorigenic characteristics, depending on environmental cues that they receive, with most studies on colon cancer supporting a tumor-inhibiting role of macrophages. Therefore, higher 

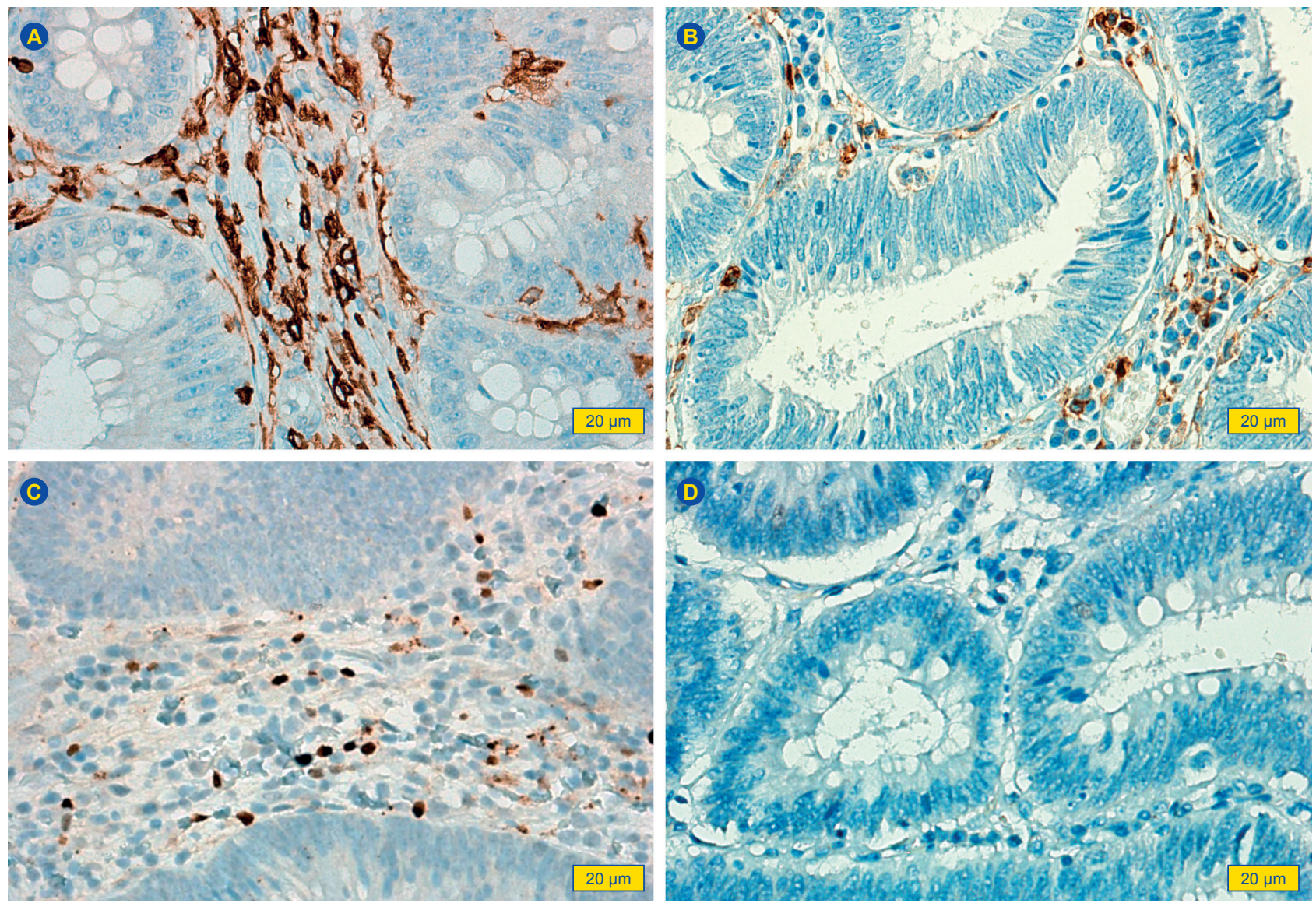

Figure 4 - High-grade dysplasia (x 40): CD4 stained cells in sporadic (A) and familial adenomatous polyposis (B) adenomas; FoxP3 stained cells in sporadic (C) and familial adenomatous polyposis adenomas (D).

Table 2 - Comparative analysis of cell counts in familial adenomatous polyposis (FAP) and sporadic (SPO) adenomas

\begin{tabular}{|c|c|c|c|c|}
\hline $\begin{array}{l}\text { Low grade dysplasia } \\
\text { (FAP versus SPO) }\end{array}$ & $\begin{array}{l}\text { FAP cell counts } \\
\text { (mean) }\end{array}$ & $\begin{array}{l}\text { Sporadic cell counts } \\
\text { (mean) }\end{array}$ & $p$-value & Statistical significance \\
\hline$C D 3$ & 1397 & 1353 & 0.8178 & ns \\
\hline$C D 4$ & 1152 & 1351 & 0.3042 & ns \\
\hline$C D 8$ & 438 & 384.3 & 0.4033 & ns \\
\hline FoxP3 & 100.3 & 246.8 & 0.0003 & $* * *$ \\
\hline CD57 & 94.92 & 91.13 & 0.9298 & ns \\
\hline$C D 68$ & 538 & 842.9 & 0.0103 & * \\
\hline $\begin{array}{l}\text { High grade dysplasia } \\
\text { (FAP versus SPO) }\end{array}$ & $\begin{array}{l}\text { FAP cell counts } \\
\text { (median) }\end{array}$ & $\begin{array}{c}\text { Sporadic cell counts } \\
\text { (median) }\end{array}$ & $p$-value & Statistical significance \\
\hline$C D 3$ & 925 & 1050 & 0.4363 & ns \\
\hline$C D 4$ & 675 & 742 & 0.0008 & $* * *$ \\
\hline$C D 8$ & 354.2 & 412.5 & 0.6665 & ns \\
\hline FoxP3 & 4.167 & 137.5 & 0.0018 & ** \\
\hline$C D 57$ & 20.83 & 25 & 0.5560 & ns \\
\hline$C D 68$ & 475 & 900 & 0.1135 & ns \\
\hline
\end{tabular}

$p \leq 0.05 ; * *: p \leq 0.01 ; * * * ; \leq 0.001 ; * * * *: p \leq 0.0001 ;$ ns: $p>0$

infiltrating densities are generally associated with decreased recurrence, diminished metastases and increased patient survival, ${ }^{45,47-49,51,52}$ which might help to explain why significantly higher counts were identified in the current study in sporadic lesions, specifically in low grade lesions, implying that its anti-tumor effect might be lost during the progression from low grade to high grade lesions.
Tumor-selective infiltration of CD4+ T cells might be explained by the role played by $\mathrm{CD} 4+$ cells during the primary antigen-specific response in imprinting CD8+ $T$ cells with the ability to develop into long-living memory cells, ${ }^{53}$ which might explain the higher counts observed in this study in high grade dysplasia lesions of sporadic patients. 


\section{CONCLUSION}

This study shows that sporadic lesions harbor higher tumor-infiltrating immune cell counts, which might reflect a higher immune tolerance towards hereditary lesions. Although these results need to be independently confirmed, it is tempting to speculate that immune tolerance may also help explain the earlier onset and multifocal pattern typically observed in hereditary lesions.

\section{ACKNOWLEDGEMENTS}

We would like to sincerely thank all the fellows, colleagues and collaborators who contributed to this work.

\section{PROTECTION OF HUMANS AND ANIMALS}

The authors declare that the procedures were followed according to the regulations established by the Clinical Research and Ethics Committee and to the Helsinki Declaration of the World Medical Association.

\section{DATA CONFIDENTIALITY}

The authors declare having followed the protocols in use at their working center regarding patients' data publication.

\section{REFERENCES}

1. Bray F, Ferlay J, Soerjomataram I, Siegel RL, Torre LA, Jemal A. Global cancer statistics 2018: GLOBOCAN estimates of incidence and mortality worldwide for 36 cancers in 185 countries. CA Cancer J Clin. 2018;68:394-424.

2. Jemal A, Siegel R, Ward E, Hao Y, Xu J, Thun MJ. Cancer statistics, 2009. CA A Cancer J Clin. 2009;59:225-49.

3. Lurje G, Zhang W, Lenz HJ. Molecular prognostic markers in locally advanced colon cancer. Clin Colorectal Cancer. 2007;6:683-90.

4. Koch M, Beckhove P, Op den Winkel J, Autenrieth D, Wagner P, Nummer D, et al. Tumor infiltrating $T$ lymphocytes in colorectal cancer: Tumor-selective activation and cytotoxic activity in situ. Ann Surg. 2006;244:986-92; discussion 92-3.

5. Finotello F, Trajanoski Z. Quantifying tumor-infiltrating immune cells from transcriptomics data. Cancer Immunol Immunother. 2018;67:103140.

6. Dalerba P, Maccalli C, Casati C, Castelli C, Parmiani G. Immunology and immunotherapy of colorectal cancer. Crit Rev Oncol Hematol. 2003;46:33-57.

7. Pages F, Berger A, Camus M, Sanchez-Cabo F, Costes A, Molidor R, et al. Effector memory T cells, early metastasis, and survival in colorectal cancer. N Engl J Med. 2005;353:2654-66.

8. Galon J, Fridman $\mathrm{WH}$, Pages F. The adaptive immunologic microenvironment in colorectal cancer: a novel perspective. Cancer Res. 2007;67:1883-6.

9. Jass JR, Love SB, Northover JM. A new prognostic classification of rectal cancer. Lancet. 1987;1:1303-6.

10. Ropponen KM, Eskelinen MJ, Lipponen PK, Alhava E, Kosma VM. Prognostic value of tumour-infiltrating lymphocytes (TILs) in colorectal cancer. J Pathol. 1997;182:318-24.

11. Nielsen HJ, Hansen U, Christensen IJ, Reimert CM, Brunner N, Moesgaard F. Independent prognostic value of eosinophil and mast cell infiltration in colorectal cancer tissue. J Pathol. 1999;189:487-95.

12. Funada Y, Noguchi T, Kikuchi R, Takeno S, Uchida Y, Gabbert HE. Prognostic significance of CD8+ T cell and macrophage peritumoral infiltration in colorectal cancer. Oncol Rep. 2003;10:309-13.

13. Deschoolmeester V, Baay M, Van Marck E, Weyler J, Vermeulen P, Lardon F, et al. Tumor infiltrating lymphocytes: an intriguing player in the survival of colorectal cancer patients. BMC Immunol. 2010;11:19.

14. Halama N, Michel S, Kloor M, Zoernig I, Benner A, Spille A, et al. Localization and density of immune cells in the invasive margin of human colorectal cancer liver metastases are prognostic for response to chemotherapy. Cancer Res. 2011;71:5670-7.

\section{CONFLICTS OF INTEREST}

The authors declare that they have no conflict of interest with regard to this article.

\section{FUNDING SOURCES}

This study was supported by: FEDER - Fundo Europeu de Desenvolvimento Regional funds through the COMPETE 2020 - Operational Programme for Competitiveness and Internationalisation (POCI), Portugal 2020, and by FCT - Fundação para a Ciência e a Tecnologia/Ministério da Ciência, Tecnologia e Inovação in the framework of the projects "Institute for Research and Innovation in Health Sciences" (POCl-01-0145-FEDER-007274), "O yin e o yang das mutações somáticas na imunovigilância do cancro" (PTDC/BIM-MEC/2834/2014), and "O papel dos Tregs na resposta imune ao cancro" (PTDC/MED-PAT/32462/2017); and by Northern Portugal Regional Programme (NORTE 2020), under the PORTUGAL 2020 Partnership Agreement, through the European Regional Development Fund (ERDF), in the framework of the project NORTE-01-0145FEDER-000029.

15. Chiba T, Ohtani H, Mizoi T, Naito Y, Sato E, Nagura H, et al. Intraepithelial CD8+ T-cell-count becomes a prognostic factor after a longer followup period in human colorectal carcinoma: possible association with suppression of micrometastasis. Br J Cancer. 2004;91:1711-7.

16. Naito Y, Saito K, Shiiba K, Ohuchi A, Saigenji K, Nagura H, et al. CD8+ $T$ cells infiltrated within cancer cell nests as a prognostic factor in human colorectal cancer. Cancer Res. 1998;58:3491-4.

17. Menon AG, Janssen-van Rhijn CM, Morreau H, Putter H, Tollenaar RA, van de Velde $\mathrm{CJ}$, et al. Immune system and prognosis in colorectal cancer: a detailed immunohistochemical analysis. Lab Invest. 2004;84:493-501.

18. Phillips SM, Banerjea A, Feakins R, Li SR, Bustin SA, Dorudi S. Tumourinfiltrating lymphocytes in colorectal cancer with microsatellite instability are activated and cytotoxic. Brit J Surg. 2004;91:469-75.

19. Koelzer $\mathrm{VH}$, Lugli $\mathrm{A}$. T-cell infiltrates and tumor budding: promising prognostic factors in the tumor microenvironment of colorectal cancer. Colorect Cancer. 2013;2:173-6.

20. Prall F, Duhrkop T, Weirich V, Ostwald C, Lenz P, Nizze H, et al. Prognostic role of CD8+ tumor-infiltrating lymphocytes in stage III colorectal cancer with and without microsatellite instability. Hum Pathol. 2004;35:808-16.

21. Salahshor S, Kressner U, Fischer H, Lindmark G, Glimelius B, Pahlman $\mathrm{L}$, et al. Microsatellite instability in sporadic colorectal cancer is not an independent prognostic factor. Brit J Cancer. 1999;81:190-3.

22. Jakubowska K, Kisielewski W, Kańczuga-Koda L, Koda M, Famulski W. Diagnostic value of inflammatory cell infiltrates, tumor stroma percentage and disease-free survival in patients with colorectal cancer. Oncol Lett. 2017;14:3869-77.

23. Colussi D, Brandi G, Bazzoli F, Ricciardiello L. Molecular pathways involved in colorectal cancer: implications for disease behavior and prevention. Int J Mol Sci. 2013;14:16365-85.

24. Fearnhead NS, Britton MP, Bodmer WF. The ABC of APC. Hum Mol Genet. 2001;10:721-33.

25. Orrù V, Steri M, Sole G, Sidore C, Virdis F, Dei M, et al. Genetic variants regulating immune cell levels in health and disease. Cell. 2013;155:24256.

26. Roederer $M$, Quaye $L$, Mangino $M$, Beddall $M H$, Mahnke $Y$, Chattopadhyay $\mathrm{P}$, et al. The genetic architecture of the human immune system: a bioresource for autoimmunity and disease pathogenesis. Cell. 2015;161:387-403.

27. Patin E, Hasan M, Bergstedt J, Rouilly V, Libri V, Urrutia A, et al. Natural variation in the parameters of innate immune cells is preferentially driven 
by genetic factors. Nat Immunol. 2018;19:302-14.

28. Galon J, Costes A, Sanchez-Cabo F, Kirilovsky A, Mlecnik B, LagorcePagès $C$, et al. Type, density, and location of immune cells within human colorectal tumors predict clinical outcome. Science. 2006;313:1960.

29. Galon J, Angell H, Bedognetti D, Marincola FM. The continuum of cancer immunosurveillance: prognostic, predictive, and mechanistic signatures. Immunity. 2013;39:11-26.

30. Mlecnik B, Tosolini M, Kirilovsky A, Berger A, Bindea G, Meatchi T, et al. Histopathologic-based prognostic factors of colorectal cancers are associated with the state of the local immune reaction. J Clin Oncol. 2011;29:610-8.

31. Pages F, Kirilovsky A, Mlecnik B, Asslaber M, Tosolini M, Bindea G, et al. In situ cytotoxic and memory $T$ cells predict outcome in patients with early-stage colorectal cancer. J Clin Oncol. 2009;27:5944-51.

32. Angell $\mathrm{H}$, Galon J. From the immune contexture to the Immunoscore: the role of prognostic and predictive immune markers in cancer. Curr Opin Immunol. 2013;25:261-7.

33. Dunn GP, Old LJ, Schreiber RD. The three Es of cancer immunoediting. Annu Rev Immunol. 2004;22:329-60.

34. Dunn GP, Bruce AT, lkeda H, Old LJ, Schreiber RD. Cancer immunoediting: from immunosurveillance to tumor escape. Nat Immunol. 2002;3:991-8.

35. Mlecnik B, Bindea G, Pages F, Galon J. Tumor immunosurveillance in human cancers. Cancer Metastasis Rev. 2011;30:5-12.

36. Coussens LM, Werb Z. Inflammation and cancer. Nature. 2002;420:8607.

37. Pollard JW. Tumour-educated macrophages promote tumour progression and metastasis. Nat Rev Cancer. 2004;4:71-8.

38. Wing K, Sakaguchi S. Regulatory T cells exert checks and balances on self tolerance and autoimmunity. Nat Immunol. 2010;11:7-13.

39. Mougiakakos D. Regulatory T cells in colorectal cancer: from biology to prognostic relevance. Cancers. 2011;3:1708-31.

40. Salama P, Phillips M, Grieu F, Morris M, Zeps N, Joseph D, et al. Tumor-infiltrating FOXP3+ $\mathrm{T}$ regulatory cells show strong prognostic significance in colorectal cancer. J Clin Oncol. 2009;27:186-92.

41. Frey DM, Droeser RA, Viehl CT, Zlobec I, Lugli A, Zingg U, et al. High frequency of tumor-infiltrating FOXP3(+) regulatory $\mathrm{T}$ cells predicts improved survival in mismatch repair-proficient colorectal cancer patients. Int J Cancer. 2010;126:2635-43.

42. Saito $T$, Nishikawa $H$, Wada $H$, Nagano $Y$, Sugiyama D, Atarashi $K$, et al.
Two FOXP3+CD4+ T cell subpopulations distinctly control the prognosis of colorectal cancers. Nat Med. 2016;22:679.

43. Bacman D, Merkel S, Croner R, Papadopoulos T, Brueckl W, Dimmler A. TGF-beta receptor 2 downregulation in tumour-associated stroma worsens prognosis and high-grade tumours show more tumourassociated macrophages and lower TGF-beta1 expression in colon carcinoma: a retrospective study. BMC Cancer. 2007;7:156.

44. Bailey C, Negus R, Morris A, Ziprin P, Goldin R, Allavena P, et al. Chemokine expression is associated with the accumulation of tumour associated macrophages (TAMs) and progression in human colorectal cancer. Clin Exp Metastasis. 2007;24:121-30.

45. Lackner C, Jukic Z, Tsybrovskyy O, Jatzko G, Wette V, Hoefler G, et al. Prognostic relevance of tumour-associated macrophages and von Willebrand factor-positive microvessels in colorectal cancer. Virchows Arch. 2004;445:160-7.

46. Nagorsen D, Voigt S, Berg E, Stein H, Thiel E, Loddenkemper C. Tumorinfiltrating macrophages and dendritic cells in human colorectal cancer: relation to local regulatory $\mathrm{T}$ cells, systemic $\mathrm{T}$-cell response against tumor-associated antigens and survival. J Transl Med. 2007;5:62.

47. Zhou Q, Peng RQ, Wu XJ, Xia Q, Hou JH, Ding Y, et al. The density of macrophages in the invasive front is inversely correlated to liver metastasis in colon cancer. J TransI Med. 2010;8:13.

48. Forssell J, Oberg A, Henriksson ML, Stenling R, Jung A, Palmqvist R. High macrophage infiltration along the tumor front correlates with improved survival in colon cancer. Clin Cancer Res. 2007;13:1472-9.

49. Khorana AA, Ryan CK, Cox C, Eberly S, Sahasrabudhe DM. Vascular endothelial growth factor, CD68, and epidermal growth factor receptor expression and survival in patients with stage II and stage III colon carcinoma: a role for the host response in prognosis. Cancer. 2003;97:960-8

50. Shabo I, Olsson H, Elkarim R, Sun XF, Svanvik J. Macrophage infiltration in tumor stroma is related to tumor cell expression of CD163 in colorectal cancer. Cancer Microenviron. 2014;7:61-9.

51. Gordon S, Martinez FO. Alternative activation of macrophages: mechanism and functions. Immunity. 2010;32:593-604.

52. Siveen KS, Kuttan G. Role of macrophages in tumour progression. Immunol Lett. 2009;123:97-102.

53. Bevan MJ. Helping the CD8(+) T-cell response. Nat Rev Immunol. 2004;4:595-602. 